Mundo Agrario vol. 18, nº 38, e058, agosto 2017. ISSN 1515-5994

Universidad Nacional de La Plata.

Facultad de Humanidades y Ciencias de la Educación.

Centro de Historia Argentina y Americana

\title{
Os movimentos sociais do campo e a Reforma Agrária do Consenso
}

The field social movements and the Consensus Agrarian Reform

\author{
Arlete Ramos dos Santos* \\ * Universidade Estadual de Santa Cruz (UESC-BA), Brasil | arlerp@hotmail.com
}

\section{PALAVRAS CHAVE RESUMO}

Agronegócio Este texto traz os resultados de uma pesquisa de pós-doutorado ${ }^{1}$ realizada na regional Extremo Sul da Bahia, que teve como objetivo de analisar a relação de parceria estabelecida entre os movimentos sociais do campo, o Estado e as empresas do agronegócio. Utilizamos a metodologia qualitativa de natureza exploratória, cujos instrumentos de coleta de dados foram análise de documentos e entrevistas semiestruturadas. O método para reflexão dos dados coletados foi o materialismo histórico dialético e os resultados apontaram que na região brasileira pesquisada está evidenciando uma nova estratégia de reforma agrária, a qual está sendo denominada de Reforma Agrária do Consenso.

\section{KEYWORDS ABSTRACT}

Agribusiness This paper presents the results of a post-doctoral research, carried out in regional Extreme South of Bahia, in order to analyze the partnership established between the rural social movements, the state and agribusiness companies . We use the qualitative method of exploratory nature, whose data collection instruments were document analysis and semi-structured interviews. The method for reflection of the collected data was the dialectical historical materialism and the results showed that the Brazilian region studied is showing a new agrarian reform strategy, which is being called Agrarian Reform of Consensus. 


\section{Introdução}

Este texto traz os resultados de uma pesquisa de pós-doutorado realizada na regional Extremo Sul da Bahia, que teve como objetivo de analisar a relação de parceria estabelecida entre os movimentos sociais do campo, o Estado (BA) e as empresas do agronegócio de eucalipto, conhecidas nos cenários nacional e internacional. No que se refere às empresas, estas têm contribuído com os movimentos sociais do campo por meio de financiamentos para a implementação de projetos pautados na agroecologia, e ainda para a construção de agroindústrias e de espaços educativos em assentamentos na região pesquisada. Como contrapartida os movimentos sociais assinaram um acordo para não ocupar as áreas pertencentes ao complexo empresarial do eucalipto, surgindo assim um novo jeito de fazer reforma agrária, pois nesse contexto se trata de um consenso entre as empresas do agronegócio e alguns movimentos sociais do campo que atuam na referida região, cujo acordo foi formalizado com a mediação do Estado para regulamentar essa relação antagônica entre o capital - representado pelo agronegócio -, e o trabalho - representado pelos camponeses.

De acordo com os representantes das empresas de eucalipto e do Estado, alguns dos movimentos sociais que participaram desse acordo foram: Movimento dos Trabalhadores Rurais Sem Terra (MST), Federação dos Trabalhadores na Agricultura (FETAG), Movimento de Luta pela Terra (MLT), Associação de Produtores Rurais Unidos Venceremos (APRUNVE), Movimento de Resistência camponesa (MRC), e a Frente de Trabalhadores Livres (FTL). Somam-se a estes vários outros movimentos sociais ainda sem grande relevância na luta pela terra na região pesquisada, os quais não foram "beneficiados” com os recursos de projetos implementados na região porque ficaram de fora das negociações realizadas no supracitado acordo. $E$ no que se refere às empresas, dentre as que integraram esse processo de negociação e que foram sujeitos da nossa pesquisa, estão a Fíbria S.A. e a Veracel Celulose S.A.

O objeto analisado exigiu a compreensão das contradições presentes na realidade pesquisada que envolve a relação entre reforma agrária, agronegócio, movimentos sociais do campo, e educação. Estes elementos já consolidados no meio científico estabelecem conexões internas nas esferas da realidade social e histórica determinada no espaço da pesquisa. Buscamos observar suas contradições não de forma linear ou ainda como oposição antinômica, mas sim como resultado das relações estabelecidas e das condições objetivas desse momento histórico.

Compreendemos nesse contexto o Estado como aparelho da classe dominante no poder, como bem observara Marx (2004), sendo o interlocutor que faz o principal papel na regulação das relações fundamentais da sociedade civil-política burguesa - as relações de produção -. Ou seja, Estado é uma instância que age a favor do capital e em desfavor dos trabalhadores, já que pode regular, mas nunca - nos marcos da sociedade capitalista - extinguir essa mediação fundamental: a exploração do trabalho pelo capital. Partindo desse parâmetro de compreensão, o Estado age por meio das políticas que adota com base no movimento da disputa em torno de projetos políticos que acontecem na sociedade sendo, pois, território da luta entre as classes sociais em confronto, porém, representará os interesses de uma determinada classe, qual seja a classe dominante, que nesse objeto em estudo é representada pelo agronegócio.

Observamos nessa relação de parceria dois aspectos contraditórios. O primeiro diz respeito à subjugação dos movimentos sociais do campo aos interesses do capitalismo agrário e do Estado, na regional Extremo Sul da Bahia, uma vez que os mesmos - principalmente o MST - têm sido reconhecidos na atualidade fazendo o enfrentamento ao agronegócio no campo. O segundo está relacionado ao interesse do agronegócio em dispor recursos para implantação de projetos agroecológicos e de formação da militância - pautados na agricultura familiar - uma vez que contraditoriamente esse segmento do mercado expandiu-se nos anos de 1970, no período da modernização conservadora, como expoente da monocultura no país, sendo exatamente este um dos motivos pelos quais têm acontecido os conflitos no campo entre o capitalismo agrário e o campesinato brasileiro na atualidade. Ao trazer para reflexão estas contradições, tentaremos discutir neste artigo sobre os 
seguintes questionamentos:

1) Como os movimentos sociais do campo, da regional Extremo Sul da Bahia, conciliam a relação entre capital e trabalho ao se inserir em um projeto de reforma agrária em parceria com o agronegócio e o Estado, uma vez que os seus interesses são dicotômicos no que tange às questões de concentração e distribuição de terra, educação, dentre outras?

2) Quais os reais objetivos dos parceiros, com destaque para o MST, ao assinarem acordos para formação de assentados e militantes, bem como para a distribuição de terras para a reforma agrária?

\section{Metodologia da pesquisa}

Realizamos uma pesquisa qualitativa de natureza exploratória. Segundo Bogdan \& Biklen (1982), essa metodologia envolve a obtenção de dados descritivos encontrados no contato direto do pesquisador com a situação estudada, enfatiza mais o processo do que o produto e se preocupa em retratar as questões relacionadas ao objeto. Para análise dos dados, estes tiveram como referência a metodologia dialética visto que “a dialética é o pensamento crítico que se propõe a compreender a "coisa em si” e sistematicamente se pergunta como é possível chegar à compreensão da realidade” (Kosik, 1997, p. 20). As categorias utilizadas para melhor compreendermos o objeto em estudo foram: totalidade, práxis, contradição e mediação, tomadas do método dialético a fim de que a realidade seja considerada como totalidade concreta.

Os dados foram coletados por meio da análise documental de relatórios das empresas encontrados online $\underline{\underline{2}}$, atas, acordos e documentos assinados pelos movimentos sociais junto ao Estado e ao Instituto Nacional de Colonização e Reforma Agrária (INCRA - BA), e em revisão bibliográfica de teses e artigos. Realizamos também entrevistas semiestruturadas com assentados e membros da direção nacional, regional e estadual do MST; membros da direção do FTL, FETAG e MLT; um executivo da empresa Veracel Celulose e dois secretários estaduais da Secretaria de Relações Institucionais da Bahia (SERIN). As entrevistas semiestruturadas “(...) permitem correções, esclarecimentos e adaptações que a tornam sobremaneira eficaz na observação das informações desejadas. E se desenrola a partir de um esquema básico, porém, não aplicado rigidamente, permitindo que o entrevistador faça as necessárias adaptações” (Ludke \& André, 1986, p.18).

Após a coleta de dados, as informações foram organizadas, sempre levando em consideração o contexto em que foram obtidas e agrupadas/sistematizadas, confrontando com o referencial teórico, havendo triangulação, no sentido de interpretá-los da maneira mais cabível possível, observando que a interpretação do conhecimento não se restringe à mera descrição factual daquilo que está codificado na lógica da linguagem (Trindade \& Fazenda, 2001). O texto foi construído buscando evitar dois riscos metodológicos: a denúncia abstrata desconectada do real e o empirismo superficial pouco explicativo. Porém, diante das evidências torna-se difícil encontrar um caminho que passe longe do denuncismo, tendo em vista que os dados evidenciaram realmente a existência de uma relação de parceria entre os respectivos movimentos sociais pesquisados, o agronegócio e o Estado. Partindo de determinações gerais e alcançando determinações específicas, sustentaremos a premissa de que a classe trabalhadora camponesa deve ser apreendida enquanto uma totalidade viva e heterogênea, e está inserida num composto de contradições do capital.

\section{Os movimentos sociais no contexto da pesquisa}

Os conflitos sociais sempre estiveram presentes na história da humanidade, até mesmo com o homem primitivo, quando ainda se organizava para a caça e a pesca, ou quando as tribos guerreavam entre si, o que caracterizava formas de organização e luta em torno de objetivos comuns ou dicotômicos. Assim, os 
conflitos sociais foram os geradores dos movimentos sociais, sendo que este termo foi criado por Von Stein, em 1840, a partir de uma leitura da emergência do mundo urbano-industrial, e se caracteriza como um termo polissêmico tendo sido utilizado também como sinônimo de protestos, grupos de interesse e de pressão, mobilizações, ações coletivas, revoltas, rebeliões, dentre outros. Tais formas de conflito estão muito presentes na região pesquisada devido à existência de indígenas, quilombolas, acampados e assentados da reforma agrária. O local escolhido para a realização da pesquisa foi a regional Extremo Sul da Bahia que fica no território de identidade, também denominado de Extremo Sul, e é constituída de 21 municípios ${ }^{3}$, ocupando uma área de $30.678 \mathrm{~km}^{2}$, com cerca de 833.307 habitantes, sendo que desses, 74\% moram na zona rural, de acordo com dados do Governo da Bahia (2014).

Trata-se de uma região com importância histórica para a nação brasileira, uma vez que foi lá que aconteceu a chegada dos portugueses ao Brasil, e apresenta vários antagonismos, pois sofre com os desmatamentos, desigualdade social e, ao mesmo tempo, apresenta um rico ecossistema com muitas praias, além de parques marinhos com trechos remanescentes da Mata Atlântica. O desenvolvimento dessa regional foi acompanhado de um lento processo de investimento público, e segundo os estudos de Malina (2013), aumentou apenas com as atividades turísticas depois da construção da BR 101, que liga a Bahia a diversas partes do país, passando pelo Estado do Espírito Santo. Atualmente, as atividades econômicas que se destacam são a pecuária, cultivos de cacau e café, bem como investimentos do agronegócio no cultivo do eucalipto. Na década de 1970 o Governo Federal passou a estimular por meio de investimentos públicos o plantio de eucalipto no território nacional. Por isso, surgiram na região Extremo Sul da Bahia, a partir de 1980, as primeiras unidades de produção e empresas de celulose, atraídas em função de relevantes fatores climáticos, o preço da terra, mão de obra barata para produzir em grandes extensões de terra. Observa-se então que a conjunção de fatores favoráveis, como a implantação de acessos rodoviários e os incentivos fiscais concedidos pelo governo nas décadas de 1970 e 1980 para o reflorestamento, estimularam a expansão da cultura do eucalipto e a introdução de empresas de papel e celulose como a Veracel, Bahia Sul e Aracruz, as quais passaram a atuar na região e atender preponderantemente a demanda do mercado externo.

Nessa regional existem atualmente vários movimentos sociais do campo. Dentre eles destacamos nesse texto apenas os que participam da parceria com o agronegócio e o Estado. Segundo o gerente de sustentabilidade da Veracel, essa parceria faz parte de um acordo realizado com a participação dos movimentos.

Os movimentos sociais por sua vez teriam que aceitar e aceitaram parte do acordo, que é recuar das áreas ocupadas após julho de 2011, ou seja, sair espontaneamente daquelas áreas, e isso aconteceu. O MST, o MLT, a FETAG, a APRUNVE, o MRC e o FTL, são seis movimentos. Sendo que desses seis movimentos os dois maiores que tem quase que oitenta por cento das áreas ocupadas é o MST com uma boa quantidade de áreas ocupadas e depois a FETAG que é o segundo movimento em termo de área ocupada nesse acordo, e depois vem o MLT que é o terceiro movimento com maior quantidade de áreas ocupadas, aí depois desses, tem outros movimentos que são menores com áreas menores. (Veracel, Pesquisa de campo).

A seguir, encontramos algumas características básicas que desses movimentos sociais que consideramos importantes para distingui-los nas suas estratégias de luta e objetivos.

a) Federação dos Trabalhadores na Agricultura (FETAG) - A história da FETAG está relacionada com a criação da base da Associação dos Lavradores Fluminenses (ALF), e da Federação das Associações dos Lavradores do Estado do Rio de Janeiro (FALERJ), as quais tinham fortes vínculos com o Partido Comunista Brasileiro (PCB). No Estado do Rio de Janeiro, os planos para a transformação das associações em sindicatos começaram a ser elaboradas a partir de meados de 1962, e até dezembro deste mesmo ano já haveria no estado 13 sindicatos reconhecidos e 23 aguardando o reconhecimento. (Barcellos, 2008). A 
Federação é uma entidade sindical de segundo grau, autônoma, sem fins lucrativos.

Através dos conflitos em que se envolveu e das representações que os tornou visíveis para a sociedade, emergiram não só debates políticos, mas também determinados parâmetros de ação e atuação, a exemplo da luta pela terra. Em 1966, a FETAG fez um convênio com o Instituo Brasileiro de Reforma Agrária (IBRA), para a assistência jurídica dos lavradores, e espaços jurídicos foram sendo construídos juntamente com a crescente presença dos advogados na resolução dos conflitos.

Com a realização do II Congresso Nacional dos Trabalhadores Rurais em 1973, convocado pela Confederação Nacional dos Trabalhadores na Agricultura (CONTAG), houve a expansão da FETAG para outras regiões do país, principalmente em decorrência das tensões em torno da construção da estrada BR101. Um novo ciclo de atividades nos conflitos de terra ocorreu após 1978, ocasião do III Congresso da FETAG, que teve intenso debate sobre legislação vigente mais não respeitada, e mudanças nas estratégias de encaminhamento das reivindicações. Em $1^{\circ}$ de setembro de 2015, a FETAG completou 52 anos de existência na Bahia.

b) Movimento de Luta pela Terra (MLT) - A gênese do MLT está relacionada à expulsão de seus fundadores do MST. Depois que saíram do MST, Damião Silva e seus irmãos Cosme, Etevaldo (já mortos) e Edivaldo fundaram o Movimento dos Desempregados do Sul da Bahia, (MDS), denominado posteriormente de MLT, em Itamaraju (BA). A primeira ocupação realizada em 1993 pelo movimento aconteceu dois meses depois, em Ilhéus (429 km ao sul de Salvador), nas fazendas Bela Vista e Santa Maria. Em 1994, o MLT ocupou a Fazenda Embaúba no município de Eunápolis com mais de 300 famílias. Os seus objetivos são a construção de uma sociedade mais justa e a transformação do camponês em sujeito da história. Para auxiliá-lo na luta pela terra busca parcerias com outros segmentos da sociedade a exemplo do Movimento Sindical de Trabalhadores Rurais (MSTR), sindicatos urbanos e ONG. A realização do seu I Congresso Nacional foi em 2013, na cidade de Formosa - GO.

c) Associação de Produtores Rurais Unidos Venceremos (APRUNVE) - Trata-se de uma associação de trabalhadores criada no dia 05 de maio de 2005, sob o CNPJ no 07.526.425/0001-88. Por meio da organização da APRUNVE 65 famílias ocuparam a Fazenda Santa Maria, de propriedade da Veracel, município de Porto Seguro - BA, no dia 04/04/2008. Segundo seu dirigente, quando estavam em fase de acampamento as famílias sofreram três despejos dos quais nenhum foi cumprido. Devido a alta produtividade das famílias, a Veracel reconheceu a importância da Associação para a região e negociou a venda da área junto ao governo do Estado para que as famílias pudessem continuar na terra. A direção, em entrevista na pesquisa de campo menciona que atualmente a APRUNVE é parceira da Veracel, e tem uma produção diversificada, com o acompanhamento da Escola Superior de Agronomia da Universidade de São Paulo (ESALQ/USP). As famílias associadas vendem as suas produções junto aos municípios da região para o Programa de Aquisição de Alimentos (PAA), por meio do qual o sistema público compra alimentos produzidos pela agricultura familiar com dispensa de licitação. O PAA é coordenado pela Secretaria Nacional de Segurança Alimentar e Nutricional (SESAN) do Ministério do Desenvolvimento Social e Combate à Fome (MDS).

d) Frente dos trabalhadores Livres (FTL) - Devido à carência de materiais publicados sobre esse movimento social as informações foram coletadas apenas por meio de pesquisa de campo, em entrevistas realizadas com a Coordenação Executiva do referido movimento no dia 20 de novembro de 2015 na regional Extremo Sul BA. O movimento social FTL é uma organização social de diversos segmentos do campo: agricultores e agricultoras familiares tradicionais, de áreas reformadas, quilombolas, acampados e demais representantes dos povos do campo na Bahia e no Brasil, suprapartidária, plurirreligiosa, e foi fundada em 2011 na Bahia. O debate de sua criação se iniciou em 2010, mas a consolidação do FTL só aconteceu em 2011. 
Na sua fundação teve a participação de lideranças vindas de outras organizações que por diversos motivos sentiram necessidade de se juntarem na defesa da Agricultura Familiar, da Reforma Agrária e da Economia Solidaria, com base em um novo modelo social, ambiental, político e econômico para a transformação da sociedade, objetivando a justiça e a solidariedade. São elas: agricultor familiar, marisqueiros, quilombolas, assentados, acampados, pescadores e catadores. O movimento surge na Bahia, com forte mobilização nos territórios de identidade: Costa do Descobrimento no Extremo Sul da Bahia, nas Comunidades Quilombolas do território de Irecê, no Médio Rio de Contas, na Bacia de Jacuípe e Território Litoral Sul.

De acordo com as dirigentes entrevistadas, não tem como demarcar qual ocupação que marcou o surgimento do FTL. De acordo com os dirigentes, as discussões para a criação do mesmo tiveram início em 2010, quando lideranças da militância da Reforma Agrária buscavam alternativas sustentáveis dialogando com várias lideranças no Estado da Bahia, tendo na pauta a proteção ao meio ambiente e a preservação da agroecológica, acesso à terra e culturas tradicionais. Porém, surgiram conflitos na Fazenda Candeal, no município de Itapebi, e, nesse momento de enfrentamento, se intensificaram o diálogo com vários territórios na Bahia devido à necessidade de unificação em torno de uma bandeira. A formalização do Movimento aconteceu em 2011, sendo que o primeiro encontro estadual foi realizado em Salvador, no ano de 2013.

e) Movimento dos Trabalhadores Rurais Sem Terra (MST) - Surgido no Brasil na década de 1980 se destaca como movimento social do campo brasileiro que tem como bandeira de luta a reforma agrária e a transformação da sociedade. Segundo Fernandes (2000, p. 87), o MST é autônomo porque suas definições não estão subordinadas a outros movimentos ou instituições como partidos, sindicatos, igrejas e outros, e é heterônomo, porque na sua luta pela reforma agrária envolve essas instituições. Todos participam apoiando a luta, entretanto, quem a faz de fato acontecer são os trabalhadores, quando se mudam para a terra com a ocupação em fase de acampamento $\underline{4}$ e depois, assentamento $\underline{\underline{5}}$.

O MST reconhece como momento de sua fundação, o $1^{\circ}$ Encontro Nacional dos Trabalhadores Rurais SemTerra ocorrido em janeiro de 1984 em Cascavel, no Paraná. Sobre o $1^{\circ}$ Congresso Nacional dos Trabalhadores Rurais Sem Terra vários autores (Gohn, 1995; Morissawa, 2001; Bezerra Neto, 1999; Caldart, 2004) afirmam que a sua realização foi em 1985, havendo similaridade nas datas.

As formas de enfrentamento adotadas pelo MST, que iniciaram no violento contexto da ditadura militar, foram marcadas por grandes lutas com setores do capital e do Estado, devido à sua estratégia que era a ocupação de terras, a qual não era aceita pelos latifundiários, pois estes se consideravam vítimas na medida em que poderiam perder a sua propriedade privada: a terra. Entretanto, desde a conquista do poder pelo PT nas eleições de 2002, esse quadro tem mudado, pois segundo Corrêa (2015, p.3), a ocupação de terras e a constituição de acampamentos têm sido progressivamente substituídas pelo enfoque no desenvolvimento econômico e social dos assentamentos já existentes via convênios e parcerias com o governo $\underline{6}$, e mesmo com parcelas do empresariado rural ${ }^{7}$. Apesar de ter se destacado como um dos movimentos sociais progressistas da atualidade, pela capacidade de agregar valores sociais e culturais com base nos ideais marxistas, pesquisas (Passa Palavra, 2010) indicam que com a chegada do Partido dos Trabalhadores (PT) ao Planalto em 2003, o MST tem se direcionado para a institucionalização e para o consenso com Estado. Nota-se então que o MST passa a ser partidário de uma corrente hegemônica defendida por alguns analistas, segundo a qual houve uma reconversão ideológica do PT e da Central Única dos Trabalhadores (CUT) em direção aos caminhos da realpolitik, adotando práticas mais negociadoras e assumindo para si diversos aspectos da perspectiva neoliberal, ocorrendo, então, uma conciliação entre capital e trabalho e a adoção de alianças pluriclassistas. Essa corrente tem sido denominada de (neo)desenvolvimentismo. 


\section{As alianças (neo)desenvolvimentistas: O Estado, os movimentos sociais e o agronegócio}

Encontramos importantes estudos sobre o desenvolvimentismo em Sampaio Jr. (2012), que o compreende como um termo vago utilizado pelo pensamento crítico para tratar dos dilemas e desafios do desenvolvimento nacional nas economias latino-americanas enredadas no círculo vicioso da dependência e do subdesenvolvimento. Foi utilizado pela burguesia na América Latina como uma arma ideológica que disseminava a crença na domesticação do sistema capitalista no momento de cristalização das estruturas econômicas e sociais (Sampaio Jr. 2012. Tal paradigma econômico se caracterizava pela falta de estabilização das economias nacionais, superexploração do trabalho, dentre outros, originando daí crises cíclicas que precisavam ser estagnadas por meio de uma reversão estrutural, articulando a industrialização e a formação da economia de forma a libertar as sociedades nacionais da situação de dependência interna e externa e da desigualdade social. Fernando Henrique Cardoso e Enzo Falleto (2004), na obra Dependência e Desenvolvimento traz reflexões teóricas que contribuem para criar um entendimento de harmonia das contradições entre a pobreza e o sistema capitalista, originadas na situação de dependência do contexto latino-americamo.

Porém, o fim desse paradigma desenvolvimentista no continente supracitado ocorreu devido à crise do modelo de industrialização por substituição das importações, a redução da acumulação de capitais e a modernização dos padrões de consumo, que gerou graves problemas econômicos e sociais nas décadas de 1980, 1990 e início dos anos 2000. No Brasil, como estratégia para sair dessa crise, ganha ressonância um novo paradigma econômico implementado pelo governo do Partido dos Trabalhadores (PT), denominado de (neo)desenvolvimentismo. Apesar de compreender que o desenvolvimentismo no Brasil ganha corpo desde 1930 com o nacional-desenvolvimentismo por meio do governo de Getúlio Vargas, nos limitaremos a discutir nesse trabalho apenas o modelo adotado pelo governo do PT, iniciado em 2003.

O (neo)desenvolvimentismo não é consenso no meio acadêmico também entre os pesquisadores ditos "progressistas", pois enquanto alguns o defendem como uma revolução econômica implementada pelo PT, capaz de mudar para melhor os rumos da classe trabalhadora, outros o designa como uma política de submissão do governo petista aos desígnios do capital por meio de alianças e consenso, traindo o maior objetivo da classe explorada que é a transformação social.

Compartilhamos do entendimento de Pinassi (2009), ao traduzir esse momento econômico da política (neo)desenvolvimentista dos governos Lula e Dilma nos seguintes termos:

Sem romper com a lógica neoliberal, o “modelo” sugere formas neokeynesianas, de modo a administrar os estragos causados pelo neoliberalismo das gestões anteriores. Segundo consta, o Estado procuraria, então, recompor sua função (de “alívio”) social - através da criação de empregos (quase sempre precários e temporários), políticas de recuperação do salário mínimo e redistribuição de renda (Bolsas Família, Escola, Desemprego etc.) -, enquanto a economia se renacionalizaria por meio de financiamentos do BNDES à reindustrialização pautada na substituição de importações. Argumentos fortemente questionáveis visto que as empresas públicas privatizadas hoje são fortemente controladas por capitais externos (vide Vale), numa lógica em que a economia transnacionalizada do sistema reconduz o Brasil ao papel produtor de bens primários para exportação (Pinassi, 2009, p. 4).

Observa-se então que existe um consenso da parte dos ideólogos protagonistas desse "novo” modelo que o crescimento se constitui na chave para o enfrentamento às desigualdades sociais. Mesmo que não se leve em conta o impacto da política global, ou ainda os efeitos da crise capitalista mundial na divisão internacional do trabalho. No afã $\underline{\underline{\theta}}$ de atenuar as consequências da ordem global sobre o crescimento, a desigualdade e a indústria, os apologetas do (neo)desenvolvimentismo não compreendem que igualdade social e soberania 
nacional se divergem dos mecanismos ortodoxos para a manutenção da estabilidade da moeda, como a competitividade internacional, ajuste fiscal, liberdade de mercado, dentre outros. A ordem então é conciliar crescimento com equidade, manifestando-se concretamente na sua totalidade como uma adequação à ordem vigente onde se mascara o real, de pura submissão ao capital, e o transmuta externamente de forma acrítica em virtude, a qual faz com que a essência do real seja escamoteada pela aparência. Assim, "a supervalorização dos fatos considerados positivos e a pura e simples desconsideração dos aspectos negativos da realidade alimentam a mitologia de que a economia brasileira estaria passando por um ciclo endógeno de crescimento com distribuição de renda e aumento da soberania nacional” (Sampaio Jr., 2012, p.12).

Para superação dessa lógica faz-se necessário mudanças radicais de enfrentamento ao sistema capitalista na política econômica brasileira, o qual só será possível a partir da luta da classe trabalhadora organizada em movimentos sociais, sindicatos, partidos, entre outros.

Dentre os movimentos sociais investigados, destacamos o MST, levando em consideração a sua relevância no cenário nacional e internacional. De acordo com os estudos realizados, a exemplo de Stédile (2013), Bogo (2009), Caldart (2004), podemos concluir que o MST inicialmente destacava-se como movimento social do campo que visava principalmente a luta pela terra e a valorização do campesinato brasileiro. Entretanto, na atualidade, outras leituras, a exemplo de Santos (2013), Hilsembeck Filho (2013), Corrêa (2015) e Pinassi (2014), bem como nos dados da nossa pesquisa de campo, têm nos demonstrado que o MST passou por intensas transformações nas últimas duas décadas, sendo que há uma notável distância qualitativa entre as suas características fundantes, que marcaram as décadas de 1980 e 1990, das expressas nos anos posteriores à chegada de Presidente Lula ao Planalto, em 2003.

De acordo com os dados evidenciados na pesquisa, assim se expressa um militante do MST ao ser entrevistado acerca das diferenças nas lutas entre os anos de 1990 e 2000:

O que difere primeiro é a convivência entre dirigentes e assentados, a clareza de como eram feitas as coisas, da amizade que tinha entre as pessoas, a forma de fazer a luta, a transparência de fazer a luta. (...) Você conquistava a terra, conquistava a educação, conquistava crédito, mas era uma conquista por que a gente fazia a mobilização de massa para conseguir isso. De 99 para cá já não são as massas que conseguem, é um grupo de pessoas que representam o Movimento. O Movimento está envolvendo com a política partidária (...) Então, dentro desse contexto, a luta e a utopia sumiram. Começaram a surgir vários vícios... Porque é uma coisa muito diferente, quando você conquista por luta, por sacrifício, de quando você conquista sem a luta. De 84 até 1999, a gente tinha muito essa questão de policiar nisso. Mas, de 2000 pra cá, muitas pessoas já tinham se desvencilhado desse pensamento anterior e, chamava até de pensamento arcaico: "a gente vive em outro mundo, um mundo tecnológico”. Muitos se deixaram levar por essa questão do consumismo acumulando bens, como militantes que estão na direção do MST, que têm duas casas na praia, andam de Hilux, esqueceram os assentamentos, foram cooptados pelo agronegócio, pela indústria da construção civil, por cargos políticos, política mesmo... (MILITANTE 1).

Observamos, assim, que o MST, assim como os demais movimentos sociais investigados, têm mudado suas estratégias ao deixar de fazer ostensivamente lutas massivas para "negociar" suas pautas com o governo ou as empresas por meio de um pequeno grupo representativo. Verificamos no trecho da entrevista questões muito presentes no que tem sido denunciado por intelectuais e militantes $\underline{9}$ que fazem parte ou não do MST, a respeito de alguns movimentos sociais que com a chegada do PT ao poder têm cedido a cooptação e até a burocratização. Opondo a essa estratégia de conciliação entre os interesses do capital e da classe trabalhadora, Mészáros (2011) postula que se a reprodução do capital se mantiver, mais cedo ou mais tarde qualquer "Estado Revolucionário" se adequará à base material capitalista, como aconteceu na União 
Soviética, e que só tem sentido tomar o poder político se for para alterar na sua essência a reprodução material da sociedade.

A burocratização tem sido um forte inimigo dos movimentos anticapitalistas e historicamente tem servido de mediação ao capital para enfraquecer a luta dos trabalhadores e dificultar a criação das condições objetivas e subjetivas para a realização da tão almejada transformação social, como destaca o Militante 3:

Em 1994, quando o governo era de direita íamos para cima, já com a política de esquerda de 2003 pra cá, caminhamos em passos lentos por estarmos do mesmo lado. Acredito que não avançamos na questão agrária nesse governo por este motivo.

Com base nesse trecho da entrevista podemos concluir que ao estabelecer como estratégia o diálogo e a parceria com o governo, os movimentos sociais têm enfraquecido a sua correlação de forças e diminuído o enfrentamento entre as classes acontecendo o que Kosik (1997, p.10) define como práxis utilitária, ou seja, "a práxis que é historicamente determinada e unilateral, baseada na divisão do trabalho, na divisão da sociedade em classes e na hierarquia de posições que sobre ela se ergue”. A práxis marxista supera a visão de prática como fim em si mesmo, como interpretação do mundo, e avança na perspectiva da transformação social. Para isso, será necessário estabelecer uma unidade consciente entre teoria e prática, para que haja, de acordo com Marx (2004), a superação da práxis utilitária e o alcance da práxis revolucionária.

\section{Os movimentos sociais e o agronegócio}

O agronegócio do eucalipto, objeto de estudo nesse texto, vem se expandindo e territorializando na regional Extremo Sul da Bahia desde o processo de modernização conservadora acontecido no Brasil no período pós1964. O termo modernização conservadora foi elaborado por Barrington Moore Júnior para se referir ao desenvolvimento do capitalismo na Alemanha e no Japão. No Brasil, a apropriação do termo se deu, primeiramente, por Alberto Passos Guimarães, para destacar o processo de modernização da agricultura, com o crescimento da agropecuária disseminado no país, sem alteração de sua estrutura fundiária provenientes da antiga sociedade pré-industrial. Foi nesse contexto que também foi implementada a Revolução Verde, caracterizada como uma política econômica para beneficiar o agronegócio no campo, a qual refere-se ao processo de introdução dos pacotes tecnológicos (com agrotóxicos, semente, máquinas e novas práticas agrícolas) nos EUA e Europa que, por conseguinte, foram disseminados em outros países do Globo.

O fluxo migratório no Brasil aconteceu, principalmente, devido à mecanicização das lavouras financiada com subsídios do Governo Federal. Observamos que foi exatamente o que aconteceu na regional Extremo Sul da Bahia, quando as empresas multinacionais do agronegócio se instalam naquela região, transformandoa em um deserto verde e expropriando os trabalhadores de suas terras ou transformando o espaço territorial em uma zona de conflito, tendo como meta o lucro e a extração de mais-valia. O período de 2001 a 2011 nessa regional foi marcado pelo enfrentamento ao agronegócio e avanço do capitalismo no campo, destacando o interesse do capital por grandes grupos econômicos, responsáveis por uma vasta concentração de terra com o apoio do estado burguês. A ação desses conglomerados econômicos de capital internacional no Extremo Sul da Bahia destaca-se principalmente pela cultura e exploração do eucalipto, intermediadas por empresas como Suzano Bahia Sul, Veracel e Belgo Mineira e Fíbria; porém aqui nos limitaremos a destacar sucintamente a Fíbria e a Veracel, pois estas fizeram parte da coleta de dados para o nosso estudo.

Com sede no município de Eunápolis - BA, e uma área de 211.000 hectares, distribuída em dez municípios na regional Extremo Sul da Bahia, a Veracel Celulose S. A. tem se consolidado no ramo do eucalipto. Segundo Renato Carneiro, que na Veracel Celulose S. A. assume a função de gerente de sustentabilidade, 
....a empresa tem um terminal marítimo no município de Belmonte, através do qual a celulose produzida na fábrica é levada até o porto oceânico de Vitória - ES, e escoada para os clientes, que por coincidência, são os maiores acionistas da empresa. (...) Fizemos recentemente a comemoração de 10.000.000 (dez milhões) de toneladas de celulose produzidas nos últimos nove anos e meio na região (Pesquisa de Campo. Entrevista realizada em 16/12/2014).

Trata-se de uma empresa de capital multinacional e tem como acionista "a norueguesa Lorenz que detém 28 \% (cujo maior acionista é o cunhado do rei da Noruega, com presença em vários lugares do mundo: na Ásia, na Europa, na América Latina - Brasil e Uruguai); 28 \% são do Banco Safra (de capital internacional, com sede em Mônaco), 28 \% são da Votorantim e 12,5 \% do Banco Nacional de Desenvolvimento (BNDES), Souza Cruz (grupo British American Tobacco), e a Fíbria, que é a maior produtora mundial de celulose”므. O BNDES emprestou US\$ 318 milhões para a construção da fábrica da Veracel (empresa da Aracruz Celulose e Stora Enso, sueco-finlandesa) na Bahia. Isso nos demonstra que o agronegócio tem sido financiado em grande parte por recursos públicos. A chegada da Veracel foi anunciada como um projeto que criaria empregos e que desenvolveria a região. Por isso, a empresa contou com empréstimos do Banco Brasileiro de Desenvolvimento (BNDES) e do Banco Europeu de Investimentos (EIB), que juntos financiaram quase a metade dos US\$ 1.25 bilhões em investimentos.

A intenção da Veracel Celulose é atingir o mercado para aumentar a produção de uma infinidade de produtos visando aumentar o consumo e o lucro, operando sustentados pelo tripé que tem como base as pessoas, o conhecimento técnico e os processos operacionais. Para maximizar o lucro a empresa intensifica a exploração do tempo do trabalhador, reduzindo o que ela considera como "perda de tempo", conforme o seu gerente administrativo e financeiro: "Avançamos também em segurança, reduzindo de 3,88 para 2,45 a nossa taxa de frequência com perda de tempo (a melhor dos últimos quatro anos)”. (Veracel, 2013, p. 4). Como nos alertou Marx (2012, p. 629), o capitalista

...diminui o tempo de trabalho na forma de tempo de trabalho necessário, para aumentá-lo na forma do trabalho excedente; põe, portanto, em medida crescente, o trabalho excedente como condição questão de vida e de morte - do necessário. Por um lado desperta à vida todos os poderes da ciência e da natureza, assim como o da cooperação e do intercâmbio sociais, para fazer que a criação da riqueza seja (relativamente) independente do tempo de trabalho empregado nela. Por outro lado, se propõe medir com o tempo de trabalho essas gigantescas forças sociais criadas de tal sorte a reduzilas aos limites requeridos para que o valor já criado se conserve como valor.

O controle do trabalho dentro dos sistemas de produção ampliou com o avanço do sistema capitalista, e é cobrado nas dimensões técnica e social que atribuem direitos e deveres aos trabalhadores, subjugando-os aos seus empregadores, pois a racionalização do tempo impõe planejamento, controle e execução de diversas atividades. As estratégias do capital para maximizar os lucros, como aumento na escala de produção, padronização da qualidade com as certificações e racionalização dos recursos conciliada com aumento da produção, consolidaram e intensificaram o controle do capital sobre o trabalho, onde os trabalhadores são apenas uma peça da engrenagem para o funcionamento do mercado, sendo destituídos de qualquer vestígio de humanização.

Assim, verificamos a atualidade dos estudos de Marx (2002), em O Capital, no capítulo que trata da renda fundiária em que a produção da riqueza é social, porém, a sua apropriação é privada, pelo capital, enquanto uma relação social. Dessa forma, a contradição gerada pela propriedade privada da terra que garante a apropriação da riqueza social é uma contradição peculiar do modo capitalista de produção, que aparece de forma explícita na particularidade da região estudada, na qual os trabalhadores ocupam terras e lutam contra a hegemonia burguesa do capitalismo no campo para ter, pelo menos, um espaço para morar juntamente com 
a sua família, pois grande parte é assalariada do agronegócio. Ipso facto, o trabalho assalariado que antes do capitalismo "era acessório das horas vagas se tornou uma necessidade, e as terras da família passaram a ser cultivadas pelas esposas e filhos em idade laboral, agora, o trabalho na própria terra é que se transformou em atividade para os domingos e feriados” (Kaustky, 1968, pp. 194-195). O capitalista precisa garantir a existência de um trabalhador "despossuído" no campo para ser explorado por meio do trabalho no complexo agroindustrial, como vem acontecendo na regional Extremo Sul da Bahia.

Outro fator de destaque que a Veracel leva em consideração para manter hegemonia do negócio de eucalipto na regional extremo Sul da Bahia é a inserção do diálogo com a comunidade. Haja vista que ela precisa fazer com que a sociedade civil a veja como merecedora de credibilidade e comprometida com o desenvolvimento regional. Por isso, ela tem feito alguns investimentos aleatórios em construção de postos de saúde, escolas e treinamento de pessoal, como salienta um indígena. Na entrevista realizada na pesquisa de campo, para se manter no território a empresa analisa os stakeholders e quais os esforços que precisa fazer, pautada no sistema de interesses e estratégias dos "negócios" que ela quer aprimorar. Com base nas definições encontradas para esse termo em sites eletrônicos $\underline{11}$ verificamos que em inglês stake significa interesse, participação, risco. Holder significa aquele que possui. Assim, stakeholder também significa parte interessada ou interveniente. Os stakeholders que são objetos de interesses para as análises da Veracel de acordo com entrevistado são: “sindicato, associação, movimento social, ministério público, prefeito”.

A racionalidade estabelecida nessa relação nos leva a refletir que os interesses mercadológicos da empresa obedecem a uma lógica que vai do universal ao singular. No âmbito do universal temos a sociedade capitalista que traz em seu bojo as contradições evidentes na relação entre capital (empresas) e trabalho (stakeholders). No regime capitalista, a contradição entre o caráter social da produção e a propriedade privada dos meios de produção é comum a todos os países capitalistas, sendo assim, uma característica universal. As contradições existem no processo de desenvolvimento de todos os fenômenos, e nesse contexto pesquisado se dá por intermédio das relações de particularidades que as empresas estabelecem com os stakeholders, observando as singularidades de cada um de acordo com o tema. Essa relação de "parceria" é preconizada pelas empresas no intuito de garantir o controle por meio das mediações evidenciadas nos "negócios”, quais sejam: mão de obra barata, diminuição dos conflitos, aquisição de terras na região subvalorizadas, dentre outras.

Também tivemos como objeto de nosso estudo a Fíbria, sendo esta uma representante do agronegócio na região pesquisada. Criada em 2009 a partir da fusão entre a Aracruz e a Votorantim, atualmente é uma grande multinacional que tem negócios em mais de 40 países. Possui capacidade produtiva de 5,3 milhões de toneladas anuais de celulose, com fábricas localizadas em Três Lagoas (MS), Aracruz (ES), Jacareí (SP) e Eunápolis (BA), onde mantém a Veracel em joint venture com a Stora Enso. Em sociedade com a Cenibra, opera o Portocel (Aracruz, ES), único porto brasileiro especializado em embarque de celulose. Atua em plantios florestais localizados nos Estados de São Paulo, Minas Gerais, Rio de Janeiro, Espírito Santo, Mato Grosso do Sul e Bahia,

...com uma base florestal total de 969 mil hectares, dos quais 343 mil hectares são destinados à conservação ambiental. Em outubro de 2012, a companhia firmou aliança estratégia com a empresa canadense Ensyn para investir no segmento de combustíveis renováveis a partir de madeira e biomassa. (Fíbria, 2014, p. 1).

A Fíbria se expandiu no Brasil como uma empresa líder em concentração fundiária. De acordo com o relatório da referida empresa, 
A Fíbria Celulose S.A. é a líder mundial no setor de celulose e fibra curta. Com três unidades e uma base florestal própria de 974,4 mil hectares, dos quais 352 mil são destinados à conservação ambiental. A companhia conta também com fornecedores de madeira independentes, que em $2011 \mathrm{~s}$ omaram 3.422 contratos e 107 hectares adicionais de produção de eucalipto. (...) Tem ações negociadas na bolsa de valores de São Paulo e Nova York, o controle acionário é exercido pela BNDESPar e pela Votorantin Industrial. (...) Atende clientes de 42 países por meio de 7 centros de distribuição em 6 escritórios e de representação em: São Paulo, Nyon (Suíça), Csomád (Hungria), Miami (Estados Unidos), Hong Kong e Pequim (ambos na China) (Fíbria, 2014, p. 30).

Assim como a Veracel, a Fíbria também trabalha com análise de sistemas de interesses por meio dos stakeholders - empregados, comunidades, fornecedores, investidores e acionistas, clientes, sociedade civil, governo e imprensa -, cuja participação nas atividades de parceria contribui para que a referida empresa demonstre mundialmente em seus relatórios de sustentabilidade os resultados lucrativos, pois

...todos os anos a Fíbria submete este material para a leitura e avaliação de importantes figuras na área de sustentabilidade e do mercado de celulose. Essas opiniões colaboram para a constante evolução da empresa em seu negócio e na sua forma de comunicação com os diversos públicos de interesse. (Fíbria, 2014, p. 18).

Na Regional Extremo Sul da Bahia, uma das formas de efetivação dessa parceria tem sido as ações do Pacto da Costa do Descobrimento, firmado entre as empresas do agronegócio e o governo do Estado. O Pacto para desenvolvimento da Costa do Descobrimento é uma parceria entre a Veracel Celulose e o Governo do Estado da Bahia. Com um investimento total aproximado de R\$ 9 milhões, até 2015, para beneficiar agricultores familiares nos municípios de Porto Seguro, Eunápolis, Belmonte, Santa Cruz Cabrália, Guaratinga, Itabela, Itagimirim, Itapebi, Mascote e Canavieiras. Segundo Carneiro, esses recursos são oriundos do incentivo à exportação, previsto na Lei Complementar n ${ }^{\text {87, de }} 1996$ (Lei Kandir), que gera créditos do Imposto de Circulação de Mercadorias e Serviços (ICMS) para empresas exportadoras. O ineditismo desta parceria é a associação das ações do Pacto com políticas públicas do Governo do Estado da Bahia, a exemplo do projeto "Vida Melhor”, que dará aos investimentos maior escala beneficiando, a médio e longo prazo, os municípios do Território da Costa do Descobrimento.

Em área específica do MST o Pacto já beneficiou por meio de edital lançado no dia 03 de setembro de 2012, a Associação dos Pequenos Produtores do Assentamento Luís Inácio Lula da Silva, conhecida como Lulão, na cidade de Santa Cruz Cabrália, com uma Agroindústria Simplificada de Hortifruticultura (ASH) $\underline{12}$. Participaram do ato de entrega o governador Jaques Wagner, o secretário estadual da Casa Civil, Rui Costa, e o diretor presidente da Veracel, Antonio Sergio Alipio. Ou seja, uma clara demonstração de parceria entre o MST e o agronegócio, na região, ainda que seja por meio de editais que reforçam a parceria público-privada.

Outra parceria de grande importância na região Extremo Sul da Bahia entre os movimentos sociais do campo, o Estado e o agronegócio, a qual foi destaque no noticiário nacional e internacional é o "Projeto Assentamentos Sustentáveis”. Trata-se de uma parceria inédita envolvendo diferentes setores da sociedade como a universidade, as três esferas do governo (municipal, estadual e federal), empresas e movimentos sociais. Para a efetivação dessa parceria foram realizados encontros nos dias 08 e 09 de junho de 2011 com representantes do governo estadual por meio SERIN, representante da Escola Superior de Agricultura Luiz de Queiroz (ESALQ/USP), o representante do grupo empresarial Fíbria Luciano Penido, lideranças dos movimentos sociais, membros da Coordenação de Desenvolvimento Agrário (CDA) da Secretária Estadual de Agricultura (SEAGRI), dirigentes do INCRA, além de representantes de universidades locais da Bahia e ONGs $\underline{13}$. O referido projeto tem como foco principal desenvolver modelos de ocupação, produção e preservação das agroflorestas locais, enfatizando a preocupação com a manutenção da biodiversidade 
regional.

Os acordos com os movimentos sociais sobre a posse das terras na região estudada foram realizados não somente com a Veracel, mas também com a Fíbria. Pois faz parte desse processo de parcerias a venda ao INCRA pelo agronegócio de áreas de terras ocupadas pelos movimentos sociais do campo, desde que estes movimentos atendam às exigências do agronegócio, como demonstra o documento abaixo.

\section{Documento 1 - Protocolo de Intenções entre o agronegócio, Movimentos sociais do campo e o Estado.}

\section{MINUTA \\ PROTOCOLO DE INTENÇŌES}

O ESTADO DA BAHIA, por intarmédio da SECRETARIA DE DESENVOLVIMENTO RURAL - SDR, CNPJ $n^{\circ}$ 21.730.63810001-58, situada à Av. Luis Viana Fliho, Avenida $n^{\circ}$. 250 - Centro Administrativo da Bahia - CvB Luis Viana Filho, INSTITUDO NACIONAL DE COLONIZACĂO E REFORMA AGRẢRIA, - Bahia, Superintendencia Estadual da Bahia -INCRA/SR05, CNPJ no 00375. a72/0007-5s localizado na Av, Ulisses Guimarbes, na 840 . Cento Salvador - Bahia Salvador pessoa juridica de direito privada, com sede no Km 24 da Rodovia BA 275 - Fazends Brasilândia, Zona Rural, municipio de Eunápolis, estado da Bahia, DECLARAM,a existência de confiilos agrárias e fundiárias e a necessidade de combater e rectuzir as hostiijiades e a violencia no meio nurd do estado da Bahia, ande a VERACEI calaborando pela busca desse endendimento apresenta 25 brags dos imoveis abel.

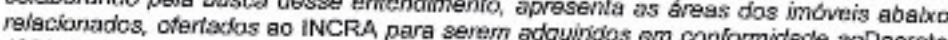
$433 / 1992$ :

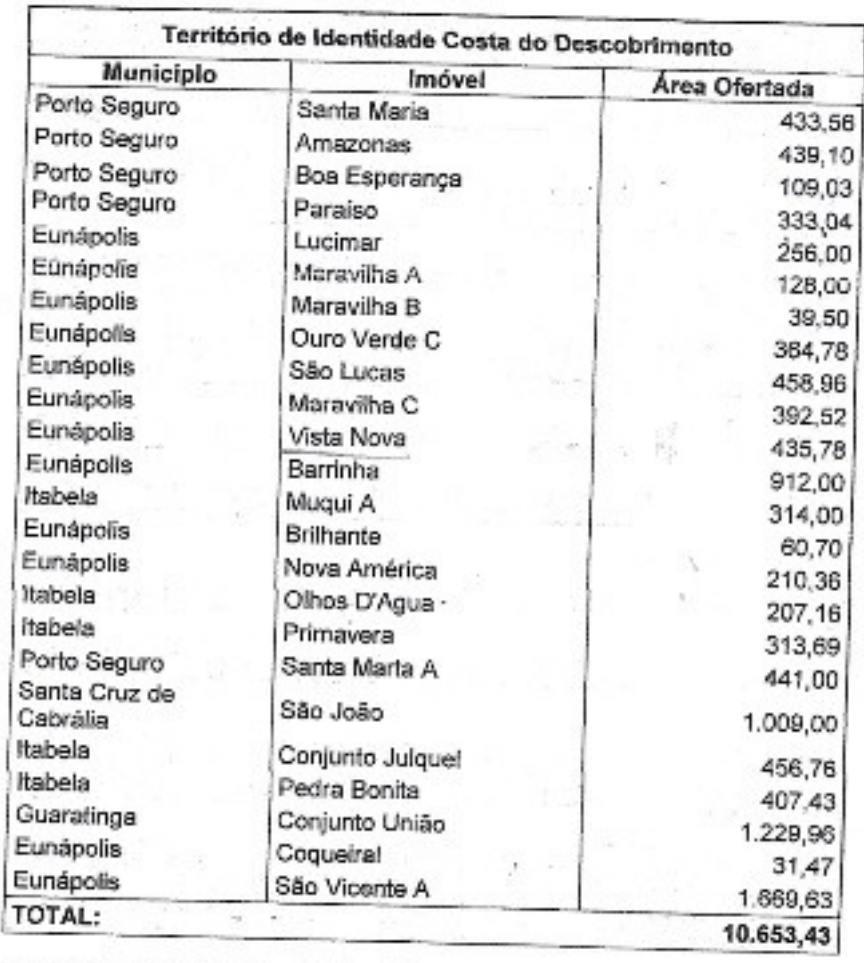

Considarando a existéncia de conflitos fundiários e agrários, e que éssa iniciativa goaduna $\$$ com a estratécia do Pcoler Executivo Federal pare acompantur iniciativa as medides de a estrategla do Pcder Executivo Federal para acompanhar e efelivar que foi gestado o combele à violéncia no campo 
VERACEL,FIBRIA,Movimentos Sociais, Govorno do Estado, da Bahia e o Instituto Nacional de Colonizaçāo e Reforma Agrária (INCRA/SR 05), devidoảnecesssidade de estabelecer um canal de dialogo com os movimentos sociais corn o objetivo de mitígar conflitos relacionados à posse da terra, diante da grande quantidade de áreas das empreasacupadss no periodo de 2008 a 2011, e o número significativo de acampamentos de trabalhadores rurais sam terra, particularmente no segundo semestre do último ano.

Os esforços conjuntos entre tais institujgöes $\theta$ instancias de Governo ratificam a necessidade de se ampliar o Programa na Bahia, berm como o reconhecimento das possibilidades de exito da Reforma Agraria nas municipios, notadamente, no Território de Identidade Costa do Descobrimento, especialmente, Porto Seguro, Eunápolis, Itabela, Santa Cruz de Cabrália e Guaratinga.

Historiando os acontecimentos, em abril de 2009, a Secretaria de Desenvolvimento Social e Combate à Pobreza, a Secretaria da Agricultura, Pecuária Irrigaçáo e Reforma Agrária - SEAGRI e a VERACEL iniciaram o processo que marcaria os primeiros passos do diálogo que juntos ompreenderiam futuramente com os movimontos scciais.

Em Outubro de 2009, em reunisa que contou com a participaçăo da Diretoria e Presidéncia da Veracel Celulose, do Secretário de Agricultura, representante da Coordenação Estadual do Movimento dos Trabalhadores Sem Terra - MST e do Instituto Nacional de Colonizaçāo e Reforma Agrária - INCRA, foram discutidas as bases iniciais de uma proposta de solução para o conflito agrário e as açōes de ocupaçбes de áfeas da VERACEL que seriam posteriomente apresentadasao Governo do Estado.

No inicio do segundo semestre de 2010, a VERACEL e o Governo do Estado, por intermádio da Secretaria de Reiaçöes Institucionais - SERINe tendo na Casa Müirar do

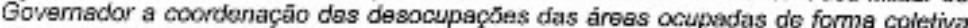
por tamilias de sem terras, abjeto de liminar de ação de reintegraçǘo de posse, apresenta um plano de desccupaçăo das fazendas acupadas.

Nesta ctapa a Secretaria de Relações Institucionaispropós à VERACEL. um projeto de assentamentos sustentáveis que $\circ$ Governo do Estado o o Movimento dos Trabalhadores Sem Terra - MST já estariam implantando com a FIBRIA sob responsabilidade técnica do Professor Paulo Kageyama (Esalq/USP).

No final de 2011 a VERACEL possuia aproximadamente 10 mil hectares do áreas ocupadas por seis Movimentos Sociais atuantes na regiāo (MST, FETAG, MLT, FTL MRC e APRUNVE), momento em que iniciou um diälogo com os Movimentos com a mediaçäo da SERIN - Secretaria de Relaçôes Institucionais do Estado da Bahia, uma iniciativa para por fim às açóes sistemáticas de ocupaçăo de terras.

Assim surge o Projeto Assentamentos Sustentáveis, projeto este de abrangéncia territorial que conta com a participaçāo do INCRA, do Estado da Bahia e com ÁVERACEL, estabelecendo um canal de diálogo com 08 Movimentos Socials voltados às questठes de conflitos relacionados à posse da terra cujas premissas săo as seguintes:

(i) A empresa reconhesef aproximadamente $10 \mathrm{mi}$ hectares de areas

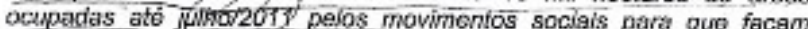
parte do acordo o sojarn ofertadas ao INCRA a CDA (Coordenaçio do

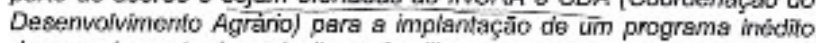
de assentomento de agricullores famörares acsmpacios nostas áress.

(ii) Aipuns isnóveis foram substîuidos, cam a anuencia dos Movimentos Socisis, para acroximar territorialmente alguns movineritos, com foco

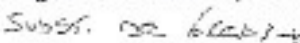

$$
\begin{aligned}
& \text { 14.000 ho. }
\end{aligned}
$$




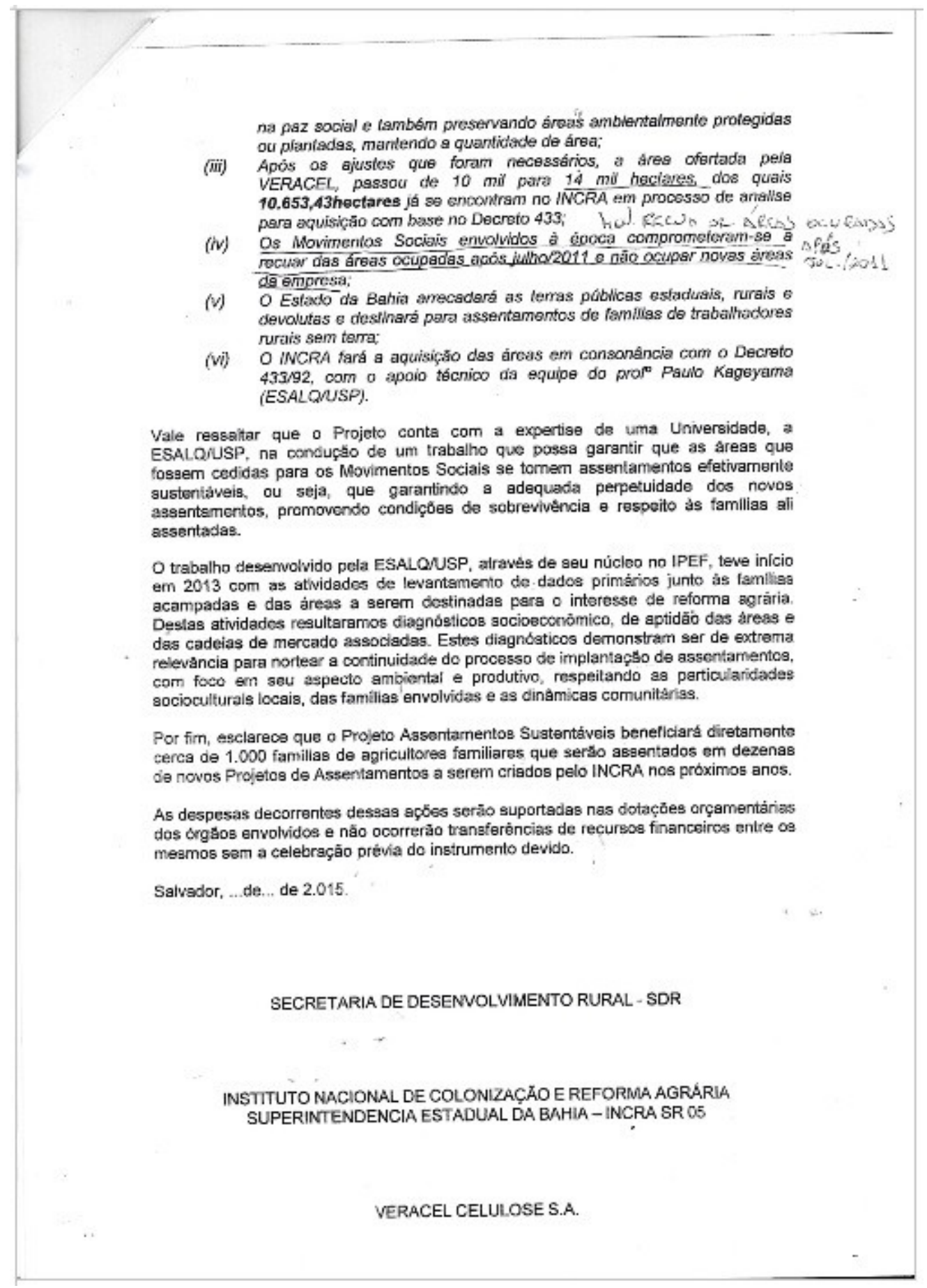

Fonte: Documento cedido pela FETAG-BA na pesquisa de campo.

A região explicitada foi uma fronteira de expansão de capitalismo agrário no Brasil, sobretudo nos anos de 1970, e está acima dos padrões de produtividade geral da agricultura na Bahia como um todo, com várias áreas de produção, "tornando-se inviável do ponto de vista da produção de terra, implementar o modelo tradicional da reforma agrária”(SERIN, pesquisa de campo). Por isso, as ocupações de terra na região geraram muitos conflitos e mortes. Para resolver o impasse e fazer um acordo, o governo estadual tentou negociar com o seguinte argumento para os empresários: 
Não dá pra vocês imaginarem que vão passar a vida toda, expulsa o povo, bota o povo pra dentro, isso não resolve. Vocês gastam muita energia, gasta energia do estado, das nossas polícias, e isso não impede que o roubo de madeira e de carvão aconteça, porque sempre vai ser um ódio mortal de um lado e do outro. Então, nós temos que pensar algo que seja bom pra todos ganharem (SERIN, Pesquisa de campo).

Para os movimentos sociais a argumentação da SERIN foi a seguinte:

Vocês sabem claramente que aqui não tem ao longo prazo condições de afirmar como assentamento. Vocês vão ter sempre essa situação de ser colocado pra fora, nunca vai ter um assentamento legalizado (...) Então, vamos ter que sair dessa situação. Vamos ter que sentar com as duas partes (SERIN, Pesquisa de campo).

Observamos a presença marcante do Estado como mediador dos conflitos sociais, numa espécie de capitalismo de Estado, sob o argumento de que "tem que ajudar a todos". O acordo originado desta mediação trata-se principalmente do convencimento dos trabalhadores para deixar documentado que a partir o mês de junho de 2011 não se ocuparia mais terra do agronegócio na região, passando a ideia de que poderia ser um "bom negócio" na medida em que as empresas capitalistas do campo também não pediriam reintegração de posse das terras que foram ocupadas até aquela data. Assim, parece originar daí um novo paradigma de reforma agrária, a partir do diálogo e consenso entre as classes antagônicas. Por isso, estamos designando-o de Reforma Agrária do Consenso. Coadunamos com o pensamento de Ariovaldo Umbelino de Oliveira, quando ele afirma que a política de reforma agrária do governo do PT está marcada por dois princípios:

Não fazê-la nas áreas de domínio do agronegócio e fazê-la apenas nas áreas onde ela possa "ajudar” o agronegócio. Ou seja, a reforma agrária está definitivamente acoplada à expansão do agronegócio no Brasil. É como se estivesse diante de uma velha desculpa: o governo (...) finge que faz a reforma agrária e divulga números maquiados na expectativa de que a sociedade possa também fingir acreditar (OLIVEIRA, 2010).

Para deixar evidente a aliança entre os parceiros com a mediação do Estado, elaboramos a tabela 1 com trechos da entrevista realizada na pesquisa de campo e também com dados coletados na internet.

\section{Tabela 1}

Diálogo dos sujeitos (Movimentos sociais, agronegócio e Estado) acerca da parceria e do consenso

\section{Sujeito da pesquisa}

Veracel - Entrevista realizada na pesquisa de campo com o gerente de sustentabilidade da empresa.

\section{Sobre a negociação e a parceria para o consenso}

Nós fizemos um trabalho de separar o joio do trigo. Bom, identificamos seis movimentos sociais, estabelecemos uma linha de corte nesse horizonte temporal de julho de 2011. Então negociamos com o governo do estado que nos ajudou a mediar. A Veracel assumia naquele momento da negociação de mesa todas as áreas que estavam ocupadas até julho de 2011. (...) Os movimentos sociais por sua vez teriam que aceitar e aceitaram parte do acordo de recuar das áreas ocupadas após julho de 2011, ou seja, sair espontaneamente daquelas áreas, e isso aconteceu (...) São seis movimentos: MST, o MLT, a FETAG, APRUNVE, o MRC e o FTL. Sendo que desses seis movimentos os dois maiores que tem quase $80 \%$ das áreas ocupadas é o MST com uma boa quantidade de áreas ocupadas, e depois a FETAG é o segundo movimento em termo de área ocupada nesse acordo. O MLT é o terceiro movimento com maior quantidade de áreas ocupadas. Aí 


\begin{tabular}{|c|c|}
\hline & depois tem movimentos que são menores com áreas menores. \\
\hline $\begin{array}{l}\text { Fíbria - Gerente de sustentabilidade } \\
\text { da Fíbria. } \\
\text { Dados adquiridos por meio de } \\
\text { correio eletrônico. }\end{array}$ & $\begin{array}{l}\text { "Prezada Professora, agradeço muito o contato. Porém, este } \\
\text { projeto que temos como a Sra pode crer, tem uma } \\
\text { complexidade particular. Nós da Fíbria, somente falamos } \\
\text { sobre ele com a concordância e alinhamento dos outros } \\
\text { parceiros (Grifo nosso), ou seja, a ESALQ e o próprio } \\
\text { movimento" }\end{array}$ \\
\hline $\begin{array}{l}\text { Estado (Bahia) - Governador da } \\
\text { Bahia, Jaques Wagner, disponível } \\
\text { em: } \\
\text { http://www.esalq.usp.br/acom/clippi } \\
\text { ng/arq } \\
\text { uivos/07-06- } \\
\underline{2012 \text { Governo MST ESALQ e Fi }} \\
\text { bria la } \\
\underline{\text { ncam centro }} \\
\underline{\text { de formacao na Bahia Pa }} \\
\text { inel Florestal PF.pdf }\end{array}$ & $\begin{array}{l}\text { "Tanto o MST quanto a empresa entenderam que o diálogo é a } \\
\text { melhor opção". }\end{array}$ \\
\hline $\begin{array}{l}\text { MST - Márcio Matos, representante } \\
\text { da Direção Nacional do MST. } \\
\text { Disponível em: } \\
\text { http://www.vermelho.org.br/noticia/ } \\
\underline{\text { 189167-8 ; }}\end{array}$ & $\begin{array}{l}1 \text { - "Chegamos a um novo paradigma de negociação sobre } \\
\text { passivos, diálogo que surgiu a partir de relações conflituosas e } \\
\text { se repetirá junto às demais empresas do setor". (Grifos nosso). } \\
2 \text { - "Neste momento, encerram-se as diferenças entre o MST e } \\
\text { Fíbria, avançando em um modelo de agricultura que possa } \\
\text { permitir ao homem produzir sem prejudicar a natureza". }\end{array}$ \\
\hline $\begin{array}{l}\text { Fetag - Ba - Dirigente da Fetag -Ba. } \\
\text { Dados adquiridos por meio de } \\
\text { correio eletrônico em 16/11/2015. }\end{array}$ & $\begin{array}{l}\text { O processo de negociação entre mov. sociais, empresas e } \\
\text { Governo iniciou com a Fazenda Colatina, Mun. do Prado, } \\
\text { quando o MST e a Fíbria, mediados pelo Governo do Estado, } \\
\text { chegaram ao consenso (grifo nosso), pondo fim ao conflito, } \\
\text { daí, se estendeu à outras propriedades da Fíbria e Suzano, } \\
\text { como também à várias áreas da Veracel, tendo sempre o } \\
\text { governo do Estado como interlocutor/mediador, envolvendo } \\
\text { uma área no município de Itapebi (Fazenda Candelária), } \\
\text { ocupada pelo MRC e FTL, uma área no município de } \\
\text { Eunápolis (Fazenda São Caetano), ocupada pela FETAG-BA e } \\
\text { MLT, várias propriedades ocupadas pelo MST e outras pela } \\
\text { FETAG-BA. No caso da FETAG-BA, o marco inicial do } \\
\text { acordo foi em outubro de dois mil e onze, quando houve uma } \\
\text { reunião em Salvador entre Veracel, FETAG-BA e Governo do } \\
\text { Estado, nesta reunião foi redigido uma ata, quando se definiu } \\
\text { que áreas ocupadas após o mês de julho de dois mil e onze } \\
\text { não seria contemplada no acordo daí em diante aconteceram } \\
\text { varias reuniões, seminários e encontros, sendo que essa } \\
\text { primeira reunião foi fruto da reivindicação da FETAG-BA } \\
\text { pedindo a intervenção do Estado no caso, em uma passeata } \\
\text { realizada em Eunápolis no ano de dois mil e onze após varias } \\
\text { reintegrações de posse em acampamentos da FETAG-BA. }\end{array}$ \\
\hline $\begin{array}{l}\text { FTL - Dirigentes do FTL } \\
\text { Dados adquiridos por meio de } \\
\text { correio eletrônico em 20/11/2015. }\end{array}$ & $\begin{array}{l}\text { Não considero uma parceria; e sim um início de “diálogo" } \\
\text { fragilizado pela postura da Veracel. Em Itagimirim temos um } \\
\text { projeto Roça do Povo que conta com alguns investimentos da } \\
\text { Veracel. Temos uma unidade de beneficiamento de Farinha } \\
\text { (edital Veracel e governo do estado) e comodato de uma área } \\
\text { de uns } 15 \text { hectares para o cultivo da mandioca. }\end{array}$ \\
\hline
\end{tabular}

Tabela construída pela autora a partir da análise dos dados coletados. 
A fala do representante da FETAG-BA apresenta uma síntese do que realmente foi acordado entre os parceiros, pois vai ao encontro do que foi dito pelo agronegócio, pelo Estado, e também pelos movimentos sociais.

Nesse acordo realizado, conforme documentos assinados pelos parceiros, demonstrados anteriormente, percebemos que acontece uma subordinação formal e real dos trabalhadores ao controle sociometabólico do capital, por meio da qual eles são levados a acreditar que o sistema capitalista está promovendo a igualdade. Porém, a instituição e o aperfeiçoamento da igualdade formal e da desigualdade substantiva pertencem ao modo de funcionamento do capital em sintonia com o princípio econômico dominante, por meio do qual os indivíduos são controlados no plano formal/legal, tanto ideologicamente como politicamente (Mészáros, 2011).

\section{Algumas conclusões possíveis...}

As questões sobre a reforma agrária pontuadas no texto trazem elementos que evidenciam a atualidade nesta forma de democratização do aceso a terra no país, pois a manutenção da concentração fundiária como resultado cada vez mais presente da territorialização do agronegócio em contraposição à territorialização do campesinato constitui um movimento em disputa no qual ainda vem gerando muitos conflitos no campo. Mas para que a reforma agrária seja utilizada como uma estratégia de desenvolvimento econômico dos camponeses faz-se necessário também a implementação de um conjunto de políticas públicas que garantam aos trabalhadores do campo condições dignas de sobrevivência. E é nesse contexto das políticas públicas que cabe a participação do Estado, a qual têm se constituído como um território de disputa pelas grandes corporações do agronegócio e também pelos movimentos e organizações socioterritoriais. Essa correlação de forças tem gerado uma conflitualidade antagônica, onde cada um destes sujeitos coletivos defendem os interesses de acordo com a sua classe.

Entretanto, o Estado brasileiro, não diferente do que Marx (2002) preconizou, está composto de um staff que responde de maneira universal aos interesses da classe dominante no poder. No tocante à reforma agrária, a tônica governamental tem sido a implementação de uma política agrícola de subordinação dos camponeses aos grandes empresários de commoditties no campo pautada no paradigma do capitalismo agrário.

É nessa acepção que se insere o que aqui denominamos de reforma agrária do consenso. Parte de um conceito de reforma agrária, idealizado pelos arautos do Estado (neo)desenvolvimentista, que afirmam implementar uma política agrária voltada para a conquista da "paz social no campo", a qual se realiza por meio de uma conciliação de interesses "negociada” entre as classes dicotômicas, representadas pelo agronegócio e os movimentos sociais do campo. A estratégia utilizada pelo Estado como parceiro, nesse contexto, é a distorção da ordem real subjacente aos interesses do capital, sendo o mediador de uma "solução pacífica” na qual as conflitualidades oriundas da ocupação de terras pelos trabalhadores não deve existir a partir de uma data estabelecida e assinada em acordos pré-estabelecidos. Ao concordar com estes termos, os parceiros que fizeram parte da "aliança profana" decretaram que naquele espaço territorial específico ocupado pelas empresas do agronegócio não haveria mais disputas por terras. Assim, estaria estabelecido um novo modo de fazer reforma agrária, fundamentado no consenso entre dominantes e dominados.

\section{Notas}

1 Pesquisa de Pós-doutorado realizada na FCLAR/UNESP, Campus Araraquara-SP, sob a supervisão da Prof ${ }^{a}$ $\mathrm{Dr}^{\mathrm{a}}$ Maria Orlanda Pinassi.

$\underline{2}$ Relatório Público de Certificação de Manejo Florestal, disponível em: http://www.bureauveritascertification.com.br/sobre-nos/relatorios-publicos\#\&panel1- 
$\underline{3}$ A regional Extremo Sul é composta pelas seguintes áreas: Belomonte, Itabela, Itagimirim, Eunápolis, Porto Seguro, Santa Cruz de Cabrália, Garatinga, Itapebi, Itamaraju, Prado, Jucuruçu, Vereda, Alcobaça, Caravelas, Teixeira de Freitas, Medeiros Neto, Itanhém, Lajedão, Ibirapuã, Mucuri e Nova Viçosa.

4 Acampamento refere-se a uma das formas de luta do MST, visualizados nos barracos construídos na margem de rodovias em áreas cuja propriedade está sendo questionada. É parte da luta pela conquista da terra, juntamente com outras formas de luta, tais como, mobilizações, passeatas, abaixo-assinado, etc. (SOUZA, 2008, p. 19).

$\underline{5}$ Assentamento refere-se à área onde os trabalhadores serão instalados, ou seja, a terra conquistada, onde os trabalhadores são assentados.

6 Sobre os convênios públicos e o desenvolvimento da agroindústria no MST ver "Com agricultura familiar, MST adere a estratégias capitalistas”, por Vasconcelos Quadros, IG São Paulo, 14/10/2013. Disponível em: http://ultimosegundo.ig.com.br/brasil/2013-10-14/com-agricultura-familiar-mst-adere-a-estrategiascapitalistas.html

$\underline{7} \mathrm{O}$ MST estabeleceu nos últimos anos parcerias com grandes empresas multinacionais, como o caso da venda de arroz orgânico via Grupo Pão de Açúcar, e mesmo convênios com empresas do setor do agronegócio, como o caso da parceria com a Fíbria (empresa resultado da fusão entre a Votorantim e a Aracruz Celulose). Sobre essas parcerias ver o artigo: "MST S/A” do Coletivo Passa Palavra, disponível em www.passapalavra.info. Ver também: “Rio+20: Pão de Açúcar irá vender arroz sem agrotóxico do MST”, UOL Notícias, Cotidiano, 20/06/2012.

8 Uma forte apologia ao (neo)desenvolvimentismo é encontrada na Tese de Doutorado de Aloísio Mercadante, defendida na UNICAMP, 2010, intitulada: “As bases do novo desenvolvimentismo: análise do governo Lula.”

9 $\mathrm{O}$ documento denominado de Carta dos 51, no qual 51 militantes assinaram e saíram do MST denuncia a burocratização e as alianças do Movimento. Pode ser lido em: "Carta de saída das nossas organizações (MST, MTD, Consulta Popular e Via Campesina) e do projeto estratégico defendido por elas”, Disponível em: http://www.passapalavra.info/2011/11/48866 , 22/11/2011. Acesso em 21/10/2015.

10 ARBEX JR., José. “Haja cruz”. Núcleo Piratininga de Comunicação, abril de 2006. Disponível em: http://www.piratininga.org.br/2006/86-arbex-cruz.html Acesso em 22/10/2015.

11 Disponível em: http://www.significados.com.br/stakeholder/

12 Os critérios para seleção, bem como a relação dos seis projetos aprovados no edital estão disponíveis no site da Veracel em: http://www.veracel.com.br/blog/noticias/comite-gestor-divulga-projetos-selecionadospara-receber-recursos-do-pacto-para-o-desenvolvimento-da/

13 Projeto Assentamentos Sustentáveis. Bahia já Jornalismo de igualdade. Disponível em: http://bahiaja.com.br/politica/noticia/2011/06/10/projeto-de-assentamentos-sustentaveis-ganha-vida-noextremo-sul,37346,0.html

\section{Referências}

Bahia. (2014). Dados da região Extremo Sul da Bahia. Fonte: http://www1.saude.ba.gov.br/mapa bahia/result macro.asp?MACRO=EXTREMO\%20SUL.

Barcellos, G. H. (2008). Desterritorialização e rexistência Tupiniquim: mulheres indígenas e o complexo agroindustrial da Aracruz Celulose. 2008, 424 f. Tese (Doutorado em Geografia)- Departamento de 
Geografia, Universidade Federal de Minas Gerais, Belo Horizonte.

Brasil. (1996). Lei Kandir. Lei Complementar $n^{\circ}$ 87, de 13 de setembro de 1996. Dispõe sobre o imposto dos Estados e do Distrito Federal sobre operações relativas à circulação de mercadorias e sobre prestações de serviços de transporte interestadual e intermunicipal e de comunicação, e dá outras providências. Disponível em: http://www.planalto.gov.br/ccivil 03/leis/LCP/Lcp87.html

Bezerra Neto, L. (1999). Sem Terra aprende e ensina: um estudo sobre as práticas educativas e formativas do Movimento dos Trabalhadores Rurais SemTerra. São Paulo: Autores Associados.

Bogdan, R. \& Bilken, S. (1982). Investigação qualitativa em educação: uma introdução à teoria e aos métodos. Porto: Porto Editora.

Bogo, A. (2009). O MST e a cultura. São Paulo: MST.

Caldart, R. S. (2004). Pedagogia do Movimento Sem Terra. Petrópolis: Vozes.

Cardoso, F. H. \& Faletto, E. (2004). Dependência e desenvolvimento na

América Latina. Rio de Janeiro: Civilização Brasileira.

Corrêa, A. E. C.(2015). O MST e a frente esquerda: o neodesenvolvimentismo em tempos de crise. VIII Colóquio Internacional Marx Engels - Cemarx / Unicamp

GT 5 - Relações de classe e lutas sociais no capitalismo contemporâneo. Campinas - SP.

Farias, L. F. C. (2013). Agronegócio e luta de classes: diferentes formas de subordinação do trabalho ao capital no complexo agroindustrial citrícola paulista. Dissertação de Mestrado. UNICAMP.

Fernandes, B. M. (2000). MST: formação e territorialização. São Paulo: HUCITEC.

Fíbria. (2014). Relatório de sustentabilidade. Fíbria Celulose S.A. Disponível em: http://www.fibria.com.br/relatorio2013/shared/relatorio-de-2013-firmes-no-rumo-7abr2014.pdf

Gohn, M. G. (1995). Movimentos e lutas sociais na história do Brasil, São Paulo: Loyola.

Hilsenbeck Filho, A. M. (2013). O MST no fio da navalha - dilemas, desafios e potencialidades da luta de classes. Tese de doutorado. Universidade Estadual de Campinas. Instituto de Filosofia e Ciências Humanas. 2013.

Kautsky, K. (1968). A questão agrária. Rio de Janeiro: Laemert.

Kosik, K. (1997). Dialética do concreto. (6. ed.) São Paulo: Paz e Terra.

Ludke, M. \& André, M. E. D. A. (1986). Pesquisa em Educação: Abordagens qualitativas. São Paulo: EPU.

Malina, L. L.(2013). A territorialização do monopólio no setor celulístico-papeleiro: a atuação da Veracel Celulose no Extremo Sul da Bahia. 2013. 358 f. Dissertação (Mestrado) - Faculdade de Filosofia, Letras e Ciências Humanas da Universidade de São Paulo, São Paulo.

Marx, K. (2012). Grundisse: manuscritos econômicos de 1857-1858. Tradução Mauro Duayer. São Paulo: Boitempo.

Marx, K. (2004). Contribuição à crítica da economia política. Tradução de Florestan Fernandes. São Paulo: Expressão Popular.

Marx, K. (2002). Manuscritos econômico-filosóficos. Tradução de Jesus Ranieri. São Paulo: Boitempo. 
Mészáros, I. (2011). Para além do capital. Tradução Sérgio Lessa. São Paulo: Boitempo.

Movimento de Luta pela Terra. (2016). História do MLT. s/d. Disponível em: http://movimentodelutapelaterra.blogspot.com.br/p/historia-do-mlt.html.

OLIVEIRA, A. J. (2010). O que significa agronegócio? Disponível em: http://www.seea.org.br/artigojoseadilson2.php.

Passa Palavra. (2012). O MST e a reforma agrária. 23 set. 2012. Disponível em: http://www.passapalavra.info/2012/09/64686 .

Pinassi, M. O. (2014). (Neo) Desenvolvimentismo ou luta de classes? VIOMUNDO, 11 jan. 2014. Disponível em: http://www.viomundo.com.br/voce-escreve/maria-orlanda-pinassi-neodesenvolvimentismo-ou-luta-declasses.html

Pinassi, M. O. (2009). O lulismo, os movimentos sociais no Brasil e o lugar social da política. Revista Herramienta, Buenos Aires.

Sampaio Jr., P. A.(2012). Desenvolvimentismo e neodesenvolvimentismo: tragédia e farsa. Serv. Soc. Soc., São Paulo, n. 112, p. 672-688, out./dez. 2012.

Santos, A. R. (2013).Ocupar, resistir e produzir também na educação. O MST e a burocracia estatal: negação e consenso - 2013. Tese de Doutorado, Faculdade de Educação, Universidade Federal de Minas Gerais, 2013. 390f.

Santos, A. R. dos ; Santos, I. T. R. dos. A Via Campesina em busca da soberania alimentar: perspectivas e desafios. (2015). Anais do II Simpósio de Direito Internacional da UFC, Fortaleza - CE, 04 a 06/11 de 2015.

Stédile, J. P. (Org.). (2013). A Questão Agrária no Brasil vol. 7. São Paulo: Expressão Popular.

Trindade, V. ; Fazenda, I. (Org). (2001). Os lugares dos sujeitos na pesquisa educacional. 2. ed. Campo Grande: UFMS.

Veracel Celulose (2013). Relatório de sustentabilidade 2013. Eunápolis: Veracel Celulose. Disponível em: http://www.veracel.com.br/default.aspx?tabid=80 